\title{
Assessment of Conflict Between Work and Studies of Students' Workers at the Hospitality Management Department of Takoradi Technical University
}

\author{
Eric Paintsil ${ }^{*}$ Sharon Atakpa Ivy Fosua Osei \\ Department of Hospitality Management, Faculty of Applied Sciences, Takoradi Technical University, Ghana
}

\begin{abstract}
The rising cost of schooling, potential labor market unpredictability and employment demands have made it necessary for a significant number of students to find jobs and opt for further education in order to fit into the job market. The purpose of the study was to assess the conflict between work and studies of students at Takoradi Technical University's Department of Hospitality Management. The research was conducted using quantitative research approach with a sample size of 60 . Probability sampling technique was the sampling technique employed in the analysis. Questionnaire was the tool used for the collection of the data and information. From the study it was identified that most students work to earn money, obtain work experience and skills in order to fulfill their academic career as well as financial responsibility that their parents and guardians cannot completely support. Therefore, the study suggested that student employees strive to negotiate with their supervisors and employers in order to reduce their workload to the level that could allow them to be more successful at work, and also to perform better at school.
\end{abstract}

Keywords: Motivation, Conflict, Studies, Students, Work

DOI: $10.7176 / \mathrm{JTHS} / 49-05$

Publication date:May $31^{\text {st }} 2020$

\section{Introduction}

Recent generations have seen a lot of changes in social spectrum in the field of work and as such taking up multiple roles with different perceptions and goals (Collins, 2011). The rising cost of education, future unpredictability on the job market and job requirement have made it essential for a large number of students to find work and to opt for further education so as to fit in the job market. According to Rosenzweig, Miele, and Differences (2016) more knowledge is required to perform more complex jobs. With the advancement of technology, people with the requisite skills and knowledge are needed to fill up certain position in the job market, hence the need to upgrade themselves.

Sinclair et al. (2014) posited that there are many contributing factors why students decide to work while schooling. Some students want to gain work experience with the available free time their lecture (class) schedule offer them. Others want to make extra money to meet the additional financial obligation or meet few people. While some students are schooling to gain more practical experience with the least possible chance, workers on the other hand, are also seeking to up-grade themselves for higher job position and offers.

Parental assistance in meeting financial obligation is not always enough to cover all expenses for the average students since some of them may be single parents, where others are doing miniature kind of work (Solis \& Durband, 2015). For this reason, many students have to find other means to accommodate or cover the extra financial burden of their studies as well as their family responsibilities. Meeting these financial obligations motivate students to work in other to earn some remuneration to cater for these requirements.

\subsection{Statement of the Problem}

The importance of balancing work with studies has gain a lot of attention by researchers over the pass decades and it is still gaining grounds on recent years. According to Ojo, Falola, Mordi, and Management (2014) balancing work with studies cover a wide range of groups including students. It is due to the effects of globalization, economic transformation, increasingly advanced technology, and the 24 hours a day 7 day work in a week culture that has changed the understanding and efficiency of jobs. In Ghana, especially the study area Takoradi Technical University (TTU), little research has beendone to find out how the situation really looks like when work is combine with studies. Moreover, the intensified working practice as well as current trends have also changed the working climate. As a result of that people who are employed in the industry in an attempt to maintain their job turn to seek for academic advancement, while those who enroll in higher academic advancement to meet the financial needs therefore work to reduce those burdens. Although, it is widely recognized that many students are employed either part-time or full, little is known about the factors that motivated them to start schooling and the challenges they face while combining work with studies. It is therefore against this backdrop that this study sought to assess the conflict between work and studies of students' workers at the hospitality management department of Takoradi Technical University. 


\section{Literature Review}

Learning and schooling has long been part of student life at the university. Nevertheless, numerous recent improvements in the student's vast funding portion of tuition and other associated educational expenses have resulted in a growing number of students participating in paid jobs over the course of the term (Neyt, Omey, Verhaest, \& Baert, 2019). While it is difficult to ascertain the exact number of students employed with a degree of precision, several studies have shown that between 50 and 60 percent of all full-time university students actually participate in some form of part-time or full-time employment (Ha, Thao, \& Son, 2016).

According to Basit et al. (2015) for a number of years university students involved in employment have been the focus of studies in the UK. Students actually participate in some form of part-time or full-time employment. The report continued that the increase was largely due to the inclusion of "private loans" which replaced "means based grants" which provided government support for university fees to a large extent. The implementation of student loans has given rise to questions about student misery and the negative effects of full-time students needing to participate in jobs on academic progress (Neyt et al., 2019). It is expected that students begin to pay for their loans whilst they are still in school, meanwhile only a minority actually pay with majority of the students having a huge debt to settle after school. However, it was argued that the principle of enormous debt incurred by students is due to their tuition fees and other associated educational expenses that impel students to participate in either full-time or part-time jobs. In addition to contribution to their educational experience, students must also pay rent, buy books and food, pay for transportation and social activities.

Several research has shown that, greater number of people who are taking up a higher academic discipline and as well working, do so usually on part- time with just few who may be engaged on full- time basis. This, however, has become the trend in the highly sophisticated academic climate and the job market. The idea of students engaged in part-time and often full-time jobs while studying is becoming more prevalent in countries like Australia and the UK. Indeed, Goh, Nguyen, Law, and Logistics (2017) found that almost nine out of ten domestic students studying hospitality and tourism management at an Australian university either worked part time or were actively looking for employment. The results match well with $\mathrm{Ha}$ et al. (2016) who established that nearly all Australian students work up to 30 hours a week to raise some funds to finance their studies. In the UK, Neyt et al. (2019) found that working part-time while studying full-time was an increasingly common trend among students and that working part-time had a range of positive outcomes, respondents generally regarded part-time jobs as a necessity for survival in the contemporary higher education sphere. It appears that students prefer to work in industries such as retail shops, hotels, and restaurants where demand for labor in Western nations has shown steady growth (Ha et al., 2016).

\subsection{Balancing Schooling with Work}

Different studies have explored the effect that part-time work can have on study of full-time students. Caiwei et al. (2018) also reported that new students who maintained a full-time academic load along with a part-time job were likely to be stressed. Indeed, it has been proposed that a combination of full-time research, part-time jobs and debt may have a detrimental effect on students 'physical and mental health and can create a perception of a negative impact on academic performance (Khasinah, Masna, Siregar, \& Humanities, 2019). Moores, Birdi, and Higson (2019) determined that those students who worked part time were more likely to miss lectures and feel that they could have achieved higher grades had they not been working. However, in the same research, Simón, Díaz, and Costa (2017) found out that there was positive outcome of working part time and that, there was no conclusive relationship between the students' marks and their perception regarding their academic performance.

A better understanding of the degree of part-time work commitments of the students is a common finding among research works. Several scholars have argued that universities should be more conscious of contemporary student life and incorporate a versatility dimension in their evaluations and requirements for courses. This can be accomplished through flexible class scheduling and the provision of research support services, especially given the number of other students common in modern universities (Jordan, 2018).

The issue regarding the impact on student performance of either part-time or full-time work is relatively under investigation and the effects of part-time work were viewed from both positive and negative perspectives. From a positive point of view, it was found that students learn personal transferable skills, which improved their level of employability and improved trust in the workplace (Neyt et al., 2019). From a negative viewpoint, a report from a study conducted by Nakanwagi (2019) in the UK showed that most of their sample worked when they were in school and concluded that students who worked had higher marks than students who did not. According to Zhu, Kim, Poulston, and Education (2019) other negative impacts found include missing lectures and tutorials, decreased research and exhaustion time, and the creation of an interest dispute between jobs and academic obligations (Neyt et al., 2019). Considering that part-time student work is popular in universities, there is a moral requirement to consider and handle more effectively the stressors faced by students studying full-time and parttime work (Caiwei et al., 2018). 


\subsection{Factors that Motivate Students to combine Schooling with Work}

The question of financial need has been discussed elsewhere in this paper and there are many studies that suggest that the obligation of the students to contribute to the high cost of their education leaves them with no choice but to engage them in part-time work (Mercer, Clay, \& Etheridge, 2016). There may be other less obvious factors, however, for students to engage in full-time or part-time jobs while studying. Specifically, students working fullor part-time have been found to improve teamwork, organizational skills development, customer service and practical skills (Roshchin, Rudakov, \& Work, 2017). Developing these skills seems more important for students who are learning a vocationally specific program such as students from HCIM. It is clear that, in addition to earning money, students involved in vocationally specific programs that work in the specific industry also have the opportunity to experience a variety of academic future prospects and advantages in the creation of skills. Consequently, a number of studies have found that, in addition to more conventional vacation work, a combination of financial need and ability to gain experience and eventually expand career prospects led students to pursue employment during their educational cycle (Roshchin et al., 2017). According to Cappelli (2014), by taking on occasional and temporary jobs, students can obtain valuable work experience and improve their potential (shortand medium-term) labor market prospects as proposed by university and college graduates.

According to their field of study, student employment has even greater positive effects on short-and mediumterm labor market outcomes in the form of lower unemployment risk, shorter time of work search and higher wages (Geel and Backes-Gellner, 2010). Besides useful job experience and a greater understanding of the business world, students who work also gain the ability to contribute to the growth of their leadership expertise, expertise in teamwork and time management, self-confidence and personal development (Robotham, 2012). Gbadamosi, Evans, Obalola, and Work (2016) proposed that students would attempt to link their term jobs, their fields of study and their potential career ambitions in order to take advantage of the benefits of part-time or full-time employment.

\subsection{Challenges faced by students while schooling and working}

Working can affect success in academia. The main aim of studying is to focus on gaining scientific knowledge to aid in the future research of the student. And if a student wants to be given enough schooling, they will spend their entire time learning. A day requires a lot of time and energy working for many hours, so students who come back home after class and work cannot focus completely on learning new information. Lack of time and tiredness after mixing up work, that student can't assimilate all the knowledge he needs for his next class. The only thing on which the students think is to rest. Limiting study time allows students to get bad marks and not pass crucial exams that can weigh on potential students. Students cannot concentrate on learning while in school, since they are tired. Many of them are idle in the last seats rather than listening to the lecturer. It often occurs that students don't attend their classes because they want more money to earn.

\section{Methodology}

The research was conducted using quantitative approach. The target population for the study was Students at the Department of Hospitality Management who were working. The sample size determination table by Krejcie and Morgan (1970) was used to determine the sample for the study. The table stated clearly that, for a population of 80 , its corresponding sample size value should be 66 . However, the total population for the study was sixty-four (64), as a result of that, the research used all the 64 as the sample size for the study. In selecting the respondents, the stratification sampling technique in accordance with the level of their respective classes were used. This led to the selection of twenty (20) respondents from Bachelor of technology II and seven (7) respondents from Bachelor of technology I respectively. With respect to respondents from the Higher National Diploma (HND) level, ten (10) were selected from HND III, seven (7) from HND II and twenty (20) from HND I. The data collection tool utilized for the study was questionnaire. This consisted of both open and close ended questions drafted for respondents to answer and comment or make suggestions where necessary. The questionnaire was personally administered to the respondents in their respective classes at the Department of Hospitality Management. After the administration of the questionnaire, respondents were given one week (8th June, 2017 to 16th June, 2017) to complete the questionnaire which were then collected personally afterwards. Statistical Package for Social Sciences (SPSS) version 21 was used to analyze the data collected.

\section{Results and Discussion}

\subsection{Socio-demographic Characteristics}

Table 4.1 presents the socio-demographic characteristics of the respondents for the study. The results indicates that, out of the 60 respondents, $57 \%$ were females whilst $43 \%$ were males. It is however evident that the female students dominated the study compared with their male counterpart. Also, with respect to age of respondents, their ages were categorized into four groups, those between the ages of 18-22 years recorded the highest of 53\%, followed by $32 \%$ indicating respondents who fell between $28-32$ years. Only 5\% of the respondents were above 33 years. This indicates that, greater number of the respondents were youth who are striving to climb the academic 
ladder in education. With regards to the educational status of respondents, $82 \%$ of them were evening students with only $18 \%$ as regular students. It is therefore anticipated that majority of the respondents opted for the evening school due to their job description or conditions whiles the few merge their regular school schedules with their work roles at their respective job discipline. Most of the respondents (75\%) were found residing in private accommodation whilst only $25 \%$ were residing in the school's halls of residence. Concerning the marital status of respondents, majority $(92 \%)$ of the respondents were unmarried while only $8 \%$ were married. However, out of the few who were married, $77 \%$ said their marital status influenced their schooling and work whiles the remaining $(23 \%)$ stated that their marital status does not have any influence on their schooling and work. With regards to respondents' sources of income to fund their education, greater number of the respondents $(67 \%)$ earn their income from the work they do and the remaining respondents (33\%) obtain their financial support from the family (Parent). This show that not all the students get financial support from their family as most them work to support their education. Nonetheless, on the notion of how often respondents receive their income, $60 \%$ said monthly and $40 \%$ indicated weekly. Concerning the Nationality of respondents all the respondents $(100 \%)$ were found to be Ghanaians. However, with regards to the ethnicity, $57 \%$ of the respondents were Akans, 23\% were Ewes and 20\% were Gas, indicating that the Akans dominated the study as regard to other ethnic group. Again, in terms of religion, $75 \%$ of the respondents were found to be Christians as against $25 \%$ who were Muslims.

Table 4.1: Socio-Demographic Characteristics of respondents $(\mathrm{N}=60)$

\begin{tabular}{llc}
\hline Socio-Demographics Characteristics & Frequency & Percentage (\%) \\
\hline Sex & 26 & 43 \\
Male & 34 & 57 \\
Female & & \\
Age & 32 & 53 \\
$18-22$ years & 6 & 10 \\
$23-27$ years & 19 & 32 \\
$28-32$ years & 3 & 5 \\
33 and above years & & \\
Educational Status & 11 & 18 \\
Regular & 49 & 82 \\
Evening & \multicolumn{2}{|}{} \\
Residential Status & 18 & 25 \\
Resident (School Hostel) & 42 & 75 \\
Non-Resident (Private) & \multicolumn{2}{|}{} \\
Marital Status & 5 & 8 \\
Single & 55 & 92 \\
Married & 0 & 0 \\
Separated & 0 & 0 \\
Divorced & & \\
\hline
\end{tabular}

Source: Fieldwork June 2017 
Table 4.1: Socio-Demographic Characteristics of respondents $(\mathrm{N}=60)$

\begin{tabular}{llc}
\hline Socio-Demographics Characteristics & Frequency & Percentage (\%) \\
\hline Influence of marital status on education and work & 14 & 23 \\
Yes & 46 & 77 \\
No & & \\
Source of Income & 40 & 67 \\
Work & 20 & 33 \\
Family & 0 & 0 \\
How often respondents received income & 24 & 40 \\
Daily & 36 & 60 \\
Weekly & & \\
Monthly & 60 & 100 \\
Nationality & 0 & 0 \\
Ghanaian & 0 & 0 \\
Ivorian & & \\
Nigerian & 12 & 20 \\
Ethnicity & 4 & 7 \\
Ga & 34 & 57 \\
Ewe & & 75 \\
Akan & 45 & 25 \\
Religion & 15 & \\
Christian & & \\
Islam & & \\
Souce: & & \\
\hline
\end{tabular}

Source: Fieldwork June 2017

\subsection{Factors that Motivated Students to Combine School with Work}

This section discussed factors that motivated students to combine work with studies. Issues regarding whether student were schooling before they started work, reasons why students combined work and schooling and the number of years students have worked were the focus of discussion.

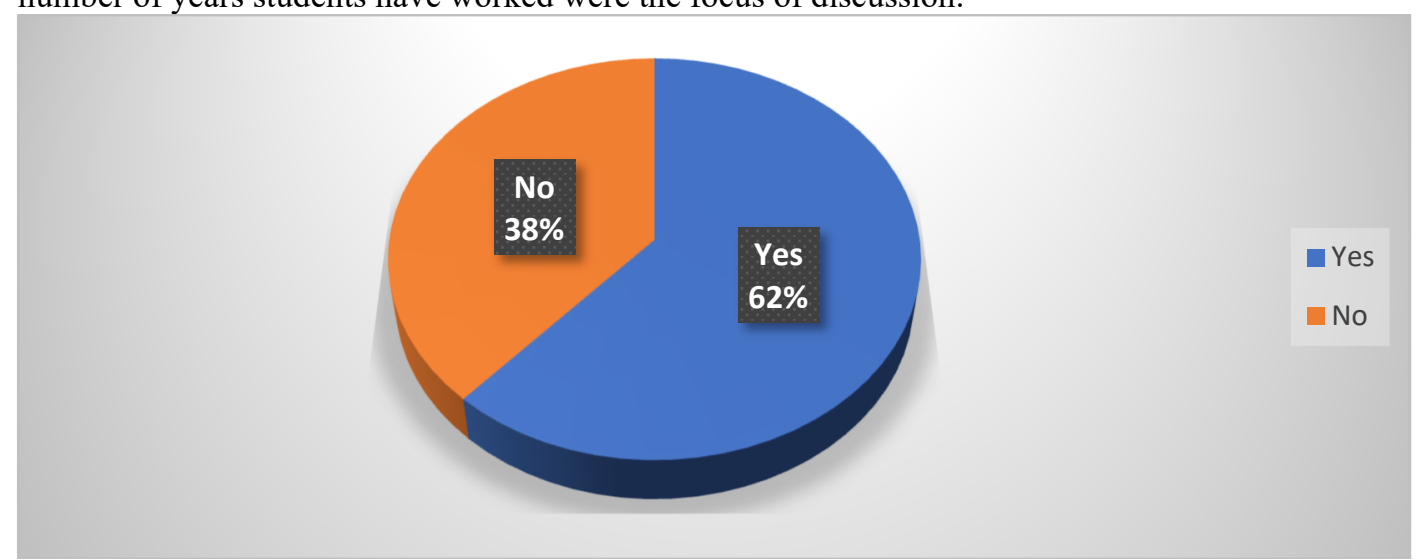

Figure 4.1: Response on whether respondents were schooling before they started working.

Source: Fieldwork, June 2017.

Greater number of the respondents $(62 \%)$ affirmed that they were schooling before they started working while $38 \%$ indicated that they were working before they started school as shown in figure 4.1. This result implied that, most of the students combine both work and school which could mean that, majority of them are working in order upgrade their competence base knowledge in order to make some money as their parents may find it difficult to assist them with all their financial aids needed. Anecdotal evidence suggest that, many students currently face economic hardship that previous generation did not experience and continued that the basic financial requirements of receiving higher knowledge in education include cover details such as, tuition fees, texts books and meal plans.

Respondents were asked the reasons that motivated them to combine their work with schooling and from the responses obtained as shown in Table $4.2,37 \%$ stated that they did so to enable them to obtain some remuneration, $33 \%$ also said they did that to gain more experience and skills, whereas the remaining $30 \%$ of the respondents indicated that they did so in order to help them prioritize their area of specialization. This implied that most students work in order to earn more income as linked with the results from the field. 
Table 4.2: Reasons why students combined work to their studies.

\begin{tabular}{lcc}
\hline Response & Frequency & Percentage (\%) \\
\hline To gain experience and skills & 20 & 33 \\
To prioritize their area specialization & 18 & 30 \\
To Earn some form of remuneration & 22 & 37 \\
Total & 60 & 100 \\
\hline
\end{tabular}

\section{Source: Field work, June 2017.}

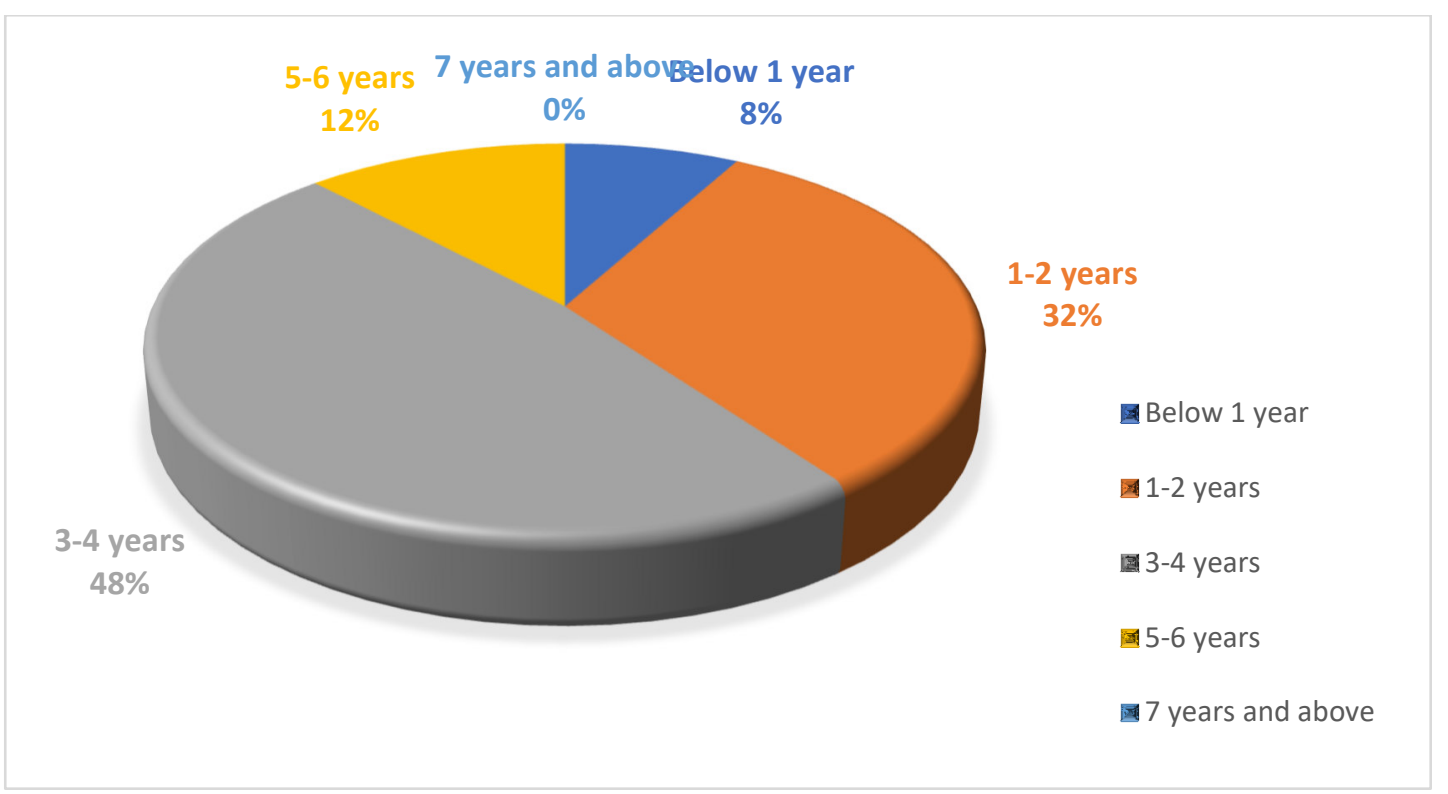

Figure 4.2: Response on years respondents have been working

Source: Fieldwork, June 2017

Further enquiries were made to ascertain the number of years that respondents have been working, and with that four main groups emanated. 48\% said they have worked for 3-4 years, 32\% had worked between 1-2 years, and respondents who have worked between 5-6 years were $12 \%$, whilst only $8 \%$ of the respondents have worked in less than 1year as shown in figure 4.2.

The results from the field clearly confirms the anecdotal evidence that, there is high labour turnover in the hospitality industry due to the nature of the job. It is however, not surprising to have only $12 \%$ who have worked between 5-6 years.

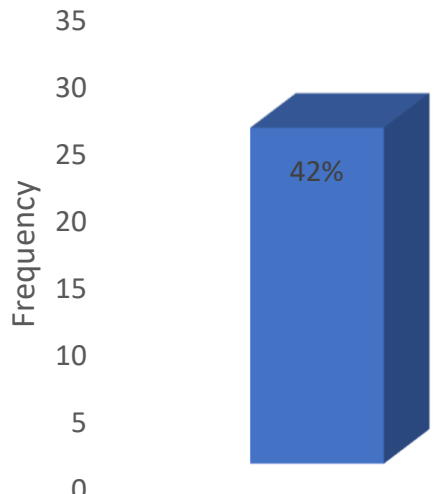

6 hours

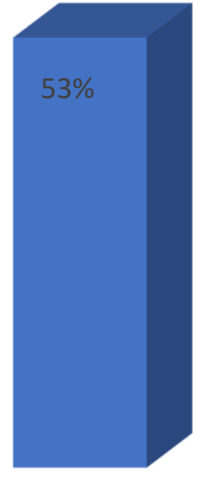

8 hours

Response

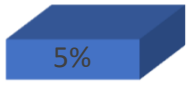

10 hours

Figure 4.3: Respondents working hours before attending lectures Source: Fieldwork, June 2017 
The number of hours people work in a day is of a great necessity to people in all walks of life as it goes a long way to contribute to their health issues. Anecdotal evidence suggest that every human being must work to the maximum of eight hours and anybody who works beyond that is considered as nothing but stress to the body. However, the details as presented in Figure 4.3 indicated that respondents' number of hours they work before they attended lectures differed considerable from one respondents to the other. It is evident from the findings that greater number of respondents (53\%) worked for 8 hours before attending lectures, $42 \%$ of the respondents worked for 6 hours and only $5 \%$ of the respondents work for 10 hours. This result shows that $53 \%$ of the students work for 8 hours before they continue with their lesson which make them stressed up. When students are stressed up in class they tend to lose concentration during lecturers which make them absent minded. According to Staff, Mortimer, and Johnson (2018) working for long hours can be particularly damaging to students' academic activities which affect their good academic performance. A study conducted by Caiwei et al. (2018) on undergraduates concerning work and study in relation to stress and found out that, students do not concentrate in class when they became stressed out.

Table 4.3: Time Respondents' usually start work

\begin{tabular}{lcc}
\hline Response & Frequency & Percentage (\%) \\
\hline 8:00 am & 31 & 52 \\
7:00 am & 11 & 18 \\
6:00 am & 18 & 30 \\
Total & $\mathbf{6 0}$ & $\mathbf{1 0 0}$ \\
\hline
\end{tabular}

\section{Source: Fieldwork, June 2017.}

The time that respondents usually started work varied considerable between 6:00 am to 8:00 am as shown in Table 4.3. It is evident that 52\% started work at 8:00 am, 30\% stated that they started work at 6:00 am leaving only $18 \%$ who also started work at 7:00 am. This implied that respondents would have to wake up early in the morning to make room for their family responsibilities before they prepare for work in order not to be late. This also mean that students do not get enough time for their academic works and thereby making them stress fatigue instead of having a relaxed mind ready for studies.

\subsection{Challenges faced by Students while Schooling and Working}

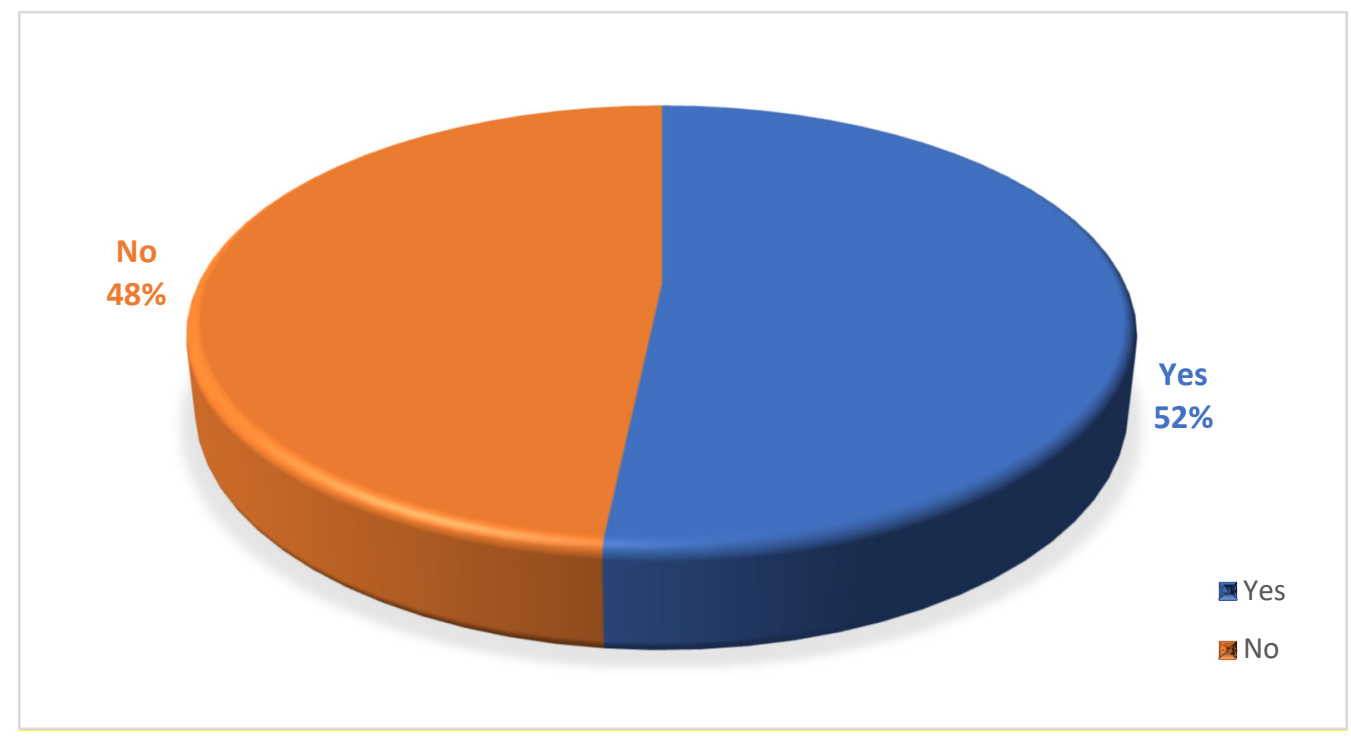

Figure 4.4: Challenges faced by students in their quests to combine work with studies.

Source: Field work, June 2017

Further questions were asked to find out whether respondents had extra-curricular activities aside work and school which mounted more pressure on both their school and work. The results as presented in figure 4.4 however, revealed that most of the respondents (52\%) affirmed that they have extra-curricular duties that they do aside work and school whereas $48 \%$ of the respondents also indicated that they do not have any extra-curricular duties apart from school and work. This indicated that more than half of the students selected for the study have other activities to attend to apart from school and work. 
Table 4.4: How respondents combine work and schooling with extra-curricular duties

\begin{tabular}{lcc}
\hline Response & Frequency & Percentage (\%) \\
\hline Apportioning time in the weekday for it & 20 & 33 \\
After school I attend to them & 10 & 17 \\
Family activities are done during the weekend & 30 & 50 \\
Total & $\mathbf{6 0}$ & $\mathbf{1 0 0}$ \\
\hline
\end{tabular}

Source: Fieldwork, June 2017.

Respondents were again asked how they combine extra-curricular duties to work and school, with that half of the respondents $(50 \%)$ said they shift all other extra activities to weekends, $33 \%$ of the respondents said they apportion time in the week day and draw time table for their extra-curriculum activities while $17 \%$ attend to extracurriculum duties after school and work duties have been attended to, as present in Table 4.4. This shows that majority of the respondents make plans to attend to extra-curricular activities effectively.

Table 4.5: Family roles respondents are directly involved with

\begin{tabular}{lcc}
\hline Response & Frequency & Percentage (\%) \\
\hline Paying siblings fees & 10 & 17 \\
Cooking for the family & 24 & 40 \\
Play mother role and guardian to nephew and nieces & 26 & 43 \\
Total & $\mathbf{6 0}$ & $\mathbf{1 0 0}$ \\
\hline
\end{tabular}

Source: Fieldwork, June 2017.

Further enquires as shown in Table 4.5, were made on the various family roles respondents were directly involved with, $40 \%$ of the respondents said they are involved in cooking for the family, $43 \%$ indicated that they wash the family clothings and attends to the younger siblings in the house including nephews and nieces with only $17 \%$ who were responsible for the paying of sibling fees. This implied that majority of the respondents were entangled with more family related duties aside schooling and work.

Table 4.6: How Schooling affect respondents Family roles

\begin{tabular}{lcc}
\hline Response & Frequency & Percentage (\%) \\
\hline Lack of time for family and children & 46 & 76 \\
Some house chores are rescheduled & 6 & 10 \\
Reach home very tired & 9 & 15 \\
Total & $\mathbf{6 0}$ & $\mathbf{1 0 0}$ \\
\hline
\end{tabular}

Source: Fieldwork, June 2017

On the notion of how schooling affect respondents' family roles, $76 \%$ of the respondents said there is lack of time and attention payed to the family needs, $23 \%$ of them also indicated that their children lack motherly love and these can lead to family crisis as it may go a long way to affect their moral upbringing. Also, $15 \%$ said they reach home very tired with only $10 \%$ who stated that some house chores are rescheduled to another day or left unattended to as present in Table 4.6. This result indicated that most often than not, students who also work face huge challenge in terms of managing their family roles at home.

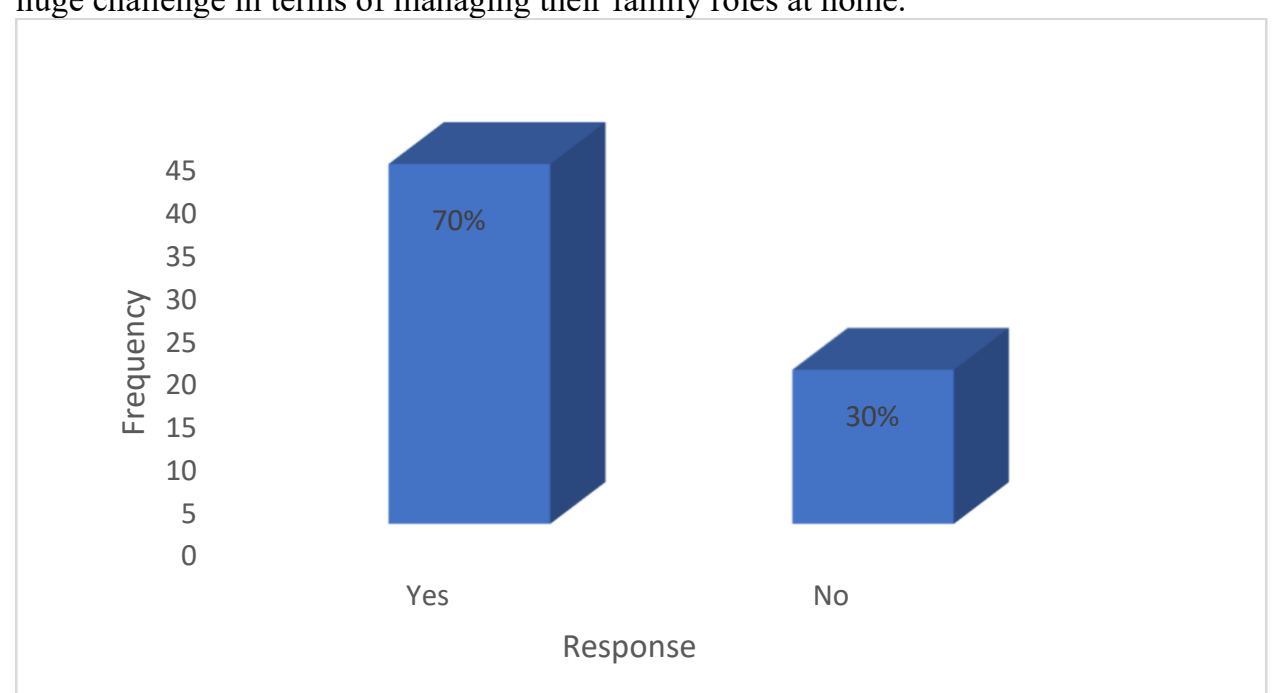

Figure 4.5: Response on whether schooling and working affect respondents' efficiency (Output)

Source: Fieldwork, June 2017

From figure 4.5 when respondents were asked whether schooling and work affect their efficiency (output) at work and school, most of the respondents (70\%) affirmed that schooling and working affect their efficiency (output) 
at work and $30 \%$ of the respondents were not in affirmation with that opinion. This implied that few of students involved in this study do perform their duties effectively both at the work place and school with majority who were affected in terms of their productivity at the workplace.

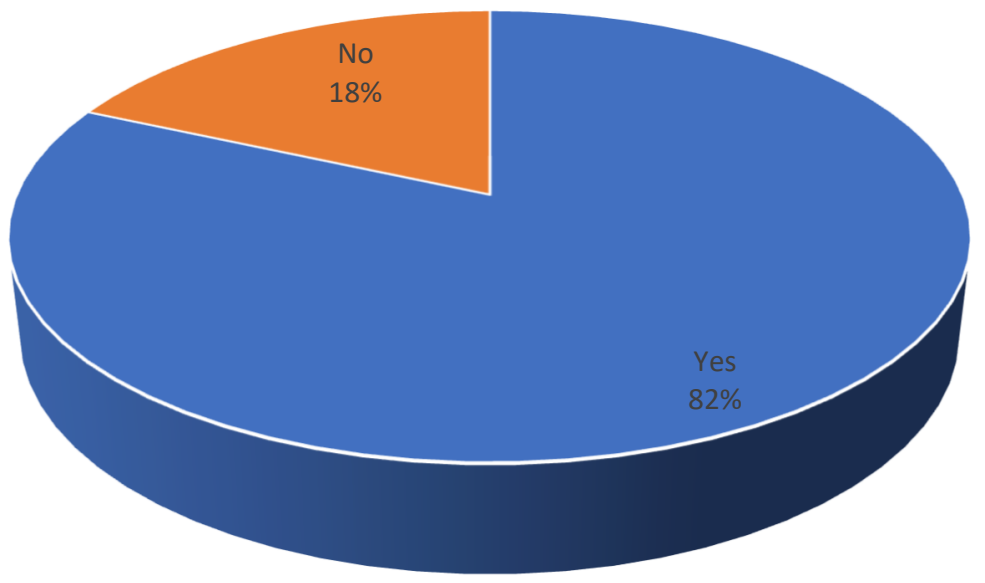

Figure 4.6: Response whether respondents' employers are satisfied with their performance Source: Fieldwork, June 2017

When respondents were asked whether their employers were happy with their performance at their respective workplaces as a result of their efficiency, majority of the respondents (82\%) said their employers like their performance and are satisfied which is contradictory of the result in Figure 4.6 however, 18\% of respondents indicated that their employers are not happy with their performance. This indicates that majority of the respondent's force to work perfectly even when they are stressed out or challenged with family and school responsibilities. This can have ripple effect on their health and could give them chronic disease in the long run.

Table 4.7: Some challenges respondents' faced in combining school and work

\begin{tabular}{lcc}
\hline Response & Frequency & Percentage (\%) \\
\hline Constant stress and fatigue and reach home tired & 42 & 65 \\
Poor performance in class and in exams & 15 & 25 \\
Lack of time for leisure & 3 & 5 \\
Total & $\mathbf{6 0}$ & $\mathbf{1 0 0}$ \\
\hline
\end{tabular}

\section{Source: Fieldwork, June 2017}

With regards to the challenges respondents faced as a result of combining school and work, as indicated in the Table 4.7, 65\% of the respondents experience constant stress and fatigue and thus reach home tired, $25 \%$ also experience poor performances both in class and exams, and $12 \%$ reach home very tired with only $5 \%$ of the respondents not having time for leisure.

Table 4.8: How the Challenges affected respondents' academic performance

\begin{tabular}{lcc}
\hline Response & Frequency & Percentage (\%) \\
\hline Result in very poor GPA & 42 & 72 \\
Failure to submit assignment & 18 & 28 \\
Total & $\mathbf{6 0}$ & $\mathbf{1 0 0}$ \\
\hline
\end{tabular}

\section{Source: Fieldwork, June 2017}

On the issue of how the challenges affect respondents' academic performance, $72 \%$ said it affect their examination grades resulting in poor GPA (Grade Point Average), while the remaining (28\%) said they always fail to submit assignment and thus affected their marks as shown in Table 4.8.

Table 4.9: How the challenges affect respondents work performance

\begin{tabular}{lcc}
\hline Response & Frequency & Percentage (\%) \\
\hline In ability to complete job task & 25 & 42 \\
Below average performance of work & 20 & 33 \\
Poor attitude to work & 10 & 17 \\
Absenteeism & 5 & 8 \\
Total & $\mathbf{6 0}$ & $\mathbf{1 0 0}$ \\
\hline
\end{tabular}

Source: Fieldwork, June 2017

Concerning how the challenges affect respondents work performance, $42 \%$ said they are unable to complete 
a given task assigned to them, 33\% said their performance at work was below average, $17 \%$ of the respondents indicated it makes them cultivate poor attitude to work and 5\% said they normally absent themselves from work since their stressed up and feel very tired which indicates signs of unhealthy lifestyle as shown in Table 4.9.

Table 4.10: How respondents manage the challenges

\begin{tabular}{lcc}
\hline Response & Frequency & Percentage (\%) \\
\hline Strategize time to meet demands & 5 & 7 \\
Learn during the night & 29 & 48 \\
Taking some days off work & 18 & 30 \\
Force to meet deadlines both at work and school & 9 & 15 \\
Total & $\mathbf{6 0}$ & $\mathbf{1 0 0}$ \\
\hline
\end{tabular}

\section{Source: Fieldwork, June 2017}

From Table 4.10, respondents were asked to state how they managed the challenges they faced, and as a result $42 \%$ said they learn during the night while $30 \%$ said they take some days off work in order to focus on their studies and also to prevent any health implementation that may be subjected to the body, $15 \%$ mentioned that they force to work to meet deadline both at work and school always whiles $5 \%$ strategize time to meet the demands from both ends.

\section{Conclusion}

It was established from the study that the major factors motivating students to combine schooling with work were to earn income, gain work experience and skills in order to meet their academic career as well as financial obligation that their parents and guardian are not able to support fully. Challenges faced by students while schooling and working were constant stress and fatigue, and usually reach home very tired and depressed which made them have less time for themselves and their family, thus created family challenges.

\section{Reference}

Basit, T. N., Eardley, A., Borup, R., Shah, H., Slack, K., \& Hughes, A. J. H. E. (2015). Higher education institutions and work-based learning in the UK: employer engagement within a tripartite relationship. 70(6), 1003-1015.

Caiwei, M., Ren, L., Chen, P. J., \& Hu, X. (2018). Exploring effective stress releasing strategies among hotel interns. CAUTHE 2018: Get Smart: Paradoxes and Possibilities in Tourism, Hospitality and Events Education and Research, 90.

Cappelli, P. H. (2015). Skill Gaps, Skill Shortages, and Skill Mismatches: Evidence and Arguments for the United States. ILR Review, 68(2), 251-290. https://doi.org/10.1177/0019793914564961

Collins, C. S. (2011). Higher education and global poverty: University partnerships and the World Bank in developing countries: Cambria Press.

Gbadamosi, G., Evans, C., Obalola, M. A. J. J. o. E., \& Work. (2016). Multitasking, but for what benefit? The dilemma facing Nigerian university students regarding part-time working. 29(8), 956-979.

Goh, E., Nguyen, S., \& Law, R. (2017). Marketing private hotel management schools in Australia. Asia Pacific Journal of Marketing and Logistics.

Ha, C. N., Thao, N. T., \& Son, T. D. (2016). Student Part-Time Employment: Case Study At Ton Duc Thang University In Vietnam.

Jordan, K. A. (2018). An Exploration of Employed College Student Experiences in Work and Leisure.

Khasinah, S., Masna, Y., Siregar, A. J. E. J. o. L., Education,, \& Humanities. (2019). THE PERCEIVED INFLUENCE OF PART-TIME TEACHING ON STUDENTS'PERFORMANCE IN MICRO-TEACHING CLASS. 7(1), 15-25.

Mercer, J., Clay, J., \& Etheridge, L. J. R. i. P.-c. e. (2016). Experiencing term-time employment as a non-traditional aged university student: a Welsh study. 21(3), 181-195.

Moores, E., Birdi, G. K., \& Higson, H. E. J. E. R. (2019). Determinants of university students' attendance. 61(4), 371-387.

Nakanwagi, H. S. B. (2019). Work-Life Balance and Academic Performance among Undergraduate Students in the College of Humanities and Social Sciences, Makerere University.

Neyt, B., Omey, E., Verhaest, D., \& Baert, S. J. J. o. E. S. (2019). Does student work really affect educational outcomes? A review of the literature. 33(3), 896-921.

Ojo, I. S., Falola, H. O., Mordi, C. J. E. J. o. B., \& Management. (2014). Work life balance policies and practices: A case study of Nigerian female university students. 6(12).

Rosenzweig, E. Q., Miele, D. B. J. L., \& Differences, I. (2016). Do you have an opportunity or an obligation to score well? The influence of regulatory focus on academic test performance. 45, 114-127.

Roshchin, S., Rudakov, V. J. J. o. E., \& Work. (2017). Patterns of student employment in Russia. 30(3), 314-338. Simón, H., Díaz, J. M. C., \& Costa, J. L. C. J. E. J. o. R. i. E. P. (2017). Analysis of university student employment 
and its impact on academic performance. 15(2), 281-306.

Sinclair, J. M., Allen, S. C., Davis, L., Goodchild, T., Messenger, J., \& Turner, S. J. (2014). Enhancing student employability skills through partnership working in STEM outreach: the University of Northampton approach. Paper presented at the Learning and Teaching Conference.

Solis, O., \& Durband, D. B. J. C. S. J. (2015). Financial support and its impact on undergraduate student financial satisfaction. 49(1), 93-105.

Staff, J., Mortimer, J. T., \& Johnson, M. K. (2018). Work Intensity and academic success. In Handbook of the Sociology of Education in the 21st Century (pp. 337-358): Springer.

Zhu, D., Kim, P. B., Poulston, J. J. J. o. H., \& Education, T. (2019). An Examination of University Student Workers' Motivations: A New Zealand Hospitality Industry Case Study. 1-14. 